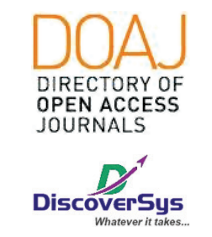

Published by DiscoverSys

\section{Profil pasien baru HIV di poliklinik VCT BRSU Tabanan Bali pada tahun 2009 sampai 2017}

\author{
R. Prawira Bayu Putra Dewa, ${ }^{1 *}$ I Gusti Ngurah Made Budiana Indrawan, ${ }^{2}$ \\ Ni Nengah Sukarni, ${ }^{3}$ Made Edwin Sridana ${ }^{1}$
}

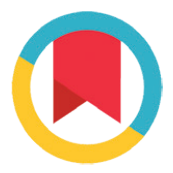

CrossMark

\title{
ABSTRACT
}

Background: HIV infection is a disease that currently becomes a global problem. Bali is one of the provinces in Indonesia with very high HIV infection new case. Badan Rumah Sakit Umum (BRSU) Tabanan is one of the leading hospitals in Tabanan. Based on data in Voluntary Counseling and Testing (VCT) clinic in BRSU Tabanan, new diagnosed HIV patients are increasing from year to year, so research about new diagnosed HIV patient profile is needed. This research is a descriptive research.

Methods: The research design used in this study is cross-sectional study. Population and sample in this study were all newly diagnosed patients with HIV infection in BRSU Tabanan VCT clinic from 2009 to 2017 with a total of 872 people were obtained by total sampling.
Secondary data were then processed statistically using statistical software.

Results: From this research obtained that new case is the most in the year $2016(18,5 \%)$. With the most patient in age $30-39$ years old age group $(34,9 \%)$, male $(60.1 \%)$, still in employment $(22.4 \%)$, still living (93.9\%), and predicted risk factor heterosexual $(93,7 \%)$. When the sample is diagnosed HIV most of the patient in stadium $3(53,6 \%)$, with the most clinical sign is weight loss more than $10 \%$ in one month (50,2\%), and opportunistic infection Candidiasis (55.6\%).

Conclusions: In an attempt to reduce spreading of HIV, education about transmitted sexual disease and reproduction health are important, especially in high-risk groups.

Keywords: HIV, Characteristic, Risk Factor, opportunistic infection, Tabanan

Cite This Article: Dewa, R.P.B.P., Indrawan, I.G.N.M.B., Sukarni, N.N., Sridana, M.E. 2018. Profil pasien baru HIV di poliklinik VCT BRSU Tabanan Bali pada tahun 2009 sampai 2017. Intisari Sains Medis 9(1): 31-36. D0I: 10.1556/ism.v9i1.145

\section{ABSTRAK}

Latar Belakang: HIV adalah penyakit yang kini sudah menjadi masalah global. Bali merupakan salah satu provinsi dengan kasus baru HIV yang sangat tinggi. Badan Rumah Sakit Umum (BRSU) Tabanan adalah salah satu rumah sakit utama di kabupaten Tabanan. Berdasarkan data poliklinikVCT BRSU Tabanan pasien baru terdiagnosis HIV tahun ke tahun terus mengalami peningkatan, sehingga perlu dilakukan penelitian profil pasien baru HIV.

Metode: Penelitian ini merupakan penelitian deskriptif dengan desain penelitian cross sectional study. Populasi dan sampel pada penelitian ini adalahseluruh pasien baruyang didiagnosisterinfeksi HIV diklinkVCTBRSU Tabanan pada tahun 2009-2017 dengan jumlah sebanyak 872 orang yang diperoleh secara total sampling. Data sekunder yang diperoleh selanjutnya diolah secara statistik dengan menggunakan software statistik.
Hasil: Dari hasil penelitian didapat kasus baru terbanyak tahun 2016 (18,5\%). Dengan karakteristik terbanyak pada usia 30 - 39 tahun $(34,9 \%)$, laki-laki $(60,1 \%)$, pekerjaan karyawan $(22,4 \%)$, status hidup $(93,9 \%)$ dan perkiraan faktor resiko heteroseksual $(93,7 \%)$. Pada saat terdiagnosis HIV sebagian besar pada stadium 3 (53,6\%), dengan gejala klinis terbanyak berat badan menurun $>10 \%$ dalam satu bulan (50,2\%), dan infeksi oportunistik terbanyak adalah Kandidiasis $(55,6 \%)$.

Simpulan: Dalam upaya menurunkan angka penularan HIV pemberian edukasi mengenai infeksi menular seksual dan kesehatan reproduksi merupakan hal yang penting, terutama pada kelompok yang beresiko tinggi.
1Fakultas Kedokteran Universitas Udayana

2SMF IImu Penyakit Dalam BRSU Tabanan

${ }^{3}$ Poliklinik VCT BRSU Tabanan

*Correspondence to:

R. Prawira Bayu Putra Dewa,

Fakultas Kedokteran Universitas

Udayana

prawirabayuputra@gmail.com

Received: 2017-12-04

Accepted: 2018-01-25

Published: 2018-01-27
Kata kunci: HIV, karakteristik, faktor resiko, infeksi oportunistik, Tabanan

Cite Pasal Ini: Dewa, R.P.B.P., Indrawan, I.G.N.M.B., Sukarni, N.N., Sridana, M.E. 2018. Profil pasien baru HIV di poliklinik VCT BRSU Tabanan Bali pada tahun 2009 sampai 2017. Intisari Sains Medis 9(1): 31-36. D0I: 10.1556/ism.v9i1.145

\section{PENDAHULUAN}

HIV adalah penyakit yang kini sudah menjadi masalah global yang serius. Hampir seluruh Negara di dunia berhadapan dengan penyakit ini, baik Negara maju dan Negara berkembang. Setiap tahunnya jumlah orang yang baru terdiagnosis HIV terus bertambah. Menurut data epidemiologi UNILADS secara global terdapat 2,2 juta jiwa didunia terdiagnosis kasus baru HIV pada 
tahun 2015. ${ }^{1}$ Begitu juga di Indonesia angka kejadian kasus baru HIV terus meningkat. Menurut data kementerian Kesehatan tahun 2016 secara nasional angka kasus baru pada tahun 2015 adalah 30.935 jiwa dan pada tahun 201641.250 jiwa. $^{2}$ Angka ini diprediksi akan terus meningkat jika tidak di tangani dengan serius. ${ }^{1}$

Bali merupakan salah satu provinsi dengan kasus baru HIV yang sangat tinggi. Pada tahun 2016 Bali merupakan provinsi ke 4 tertinggi di Indonesia dengan angka kejadian baru HIV yaitu 2.367 jiwa. ${ }^{2}$ Tabanan merupakan salah satu Kabupaten di Bali dengan angka kejadian HIV cukup tinggi. Berdasarkan data profil Kesehatan Kabupaten Tabanan tahun 2015, Kabupaten Tabanan kini sedang berfokus mencapai Millennium Development Goals (MDGs), dimana salah satu indikatornya adalah penyakit HIV. Untuk mencapai tujuan tersebut maka fasilitas kesehatan di Kabupaten Tabanan terus melakukan upaya-upaya untuk menangani masalah HIV kabupaten di Tabanan. ${ }^{3}$

Badan Rumah Sakit Umum (BRSU) Tabanan adalah salah satu rumah sakit utama di kabupaten Tabanan. BRSU Tabanan merupakan rumah sakit tipe B milik pemerintah Kabupaten Tabanan yang terletak di jantung kota Tabanan. Salah satu fasilitas BRSU Tabanan adalah poliklinik VCT. ${ }^{4}$ Poliklinik VCT BRSU Tabanan berdiri sejak tahun 2009. Berdasarkan data pasien HIV poliklinik VCT dari tahun ke tahun terus mengalami peningkatan, pada tahun 2016 terdapat 161 jiwa yang terdiagnosis baru HIV. Poliklinik VCT BRSU Tabanan terus berusaha dengan baik untuk mencegah dan menurunkan angka kejadian HIV di Kabupaten Tabanan dengan berbagai upaya seperti skrining pada orang-orang yang berisiko, pemberian terapi antiretroviral, edukasi dan berbagai upaya lainnya. ${ }^{5}$

Penelitian ini dilakukan untuk mengetahui gambaran profil pasien baru positifHIV di poliklinik VCT BRSU Tabanan. Diharapkan dari penelitian ini diketahui gejala klinis, faktor risiko, dan infeksi oportunistik yang paling banyak ditemukan pada pasien HIV sehingga dapat memaksimalkan upaya pencegahan penularan HIV.

\section{METODE}

Penelitian ini menggunakan metode cross sectional, dimana datanya berasal dari data sekunder pada klinik VCT di BRSU Tabanan. Data merupakan seluruh pasien yang telah dinyatakan positif HIV dari Januari 2009 hingga Agustus 2017. Data didapatkan dari catatan register pasien yang berisikan identitas, stadium, status, gejala awal dan infeksi oportunistik saat melakukan kunjungan pada klinik VCT.
Sampel yang digunakan pada penelitian ini adalah pasien yang dinyatakan reaktif dengan pemeriksaan rapid test (Point of care/POC) dengan memakai tiga reagen yang berbeda dan pasien yang sudah dinyatakan positif HIV pada puskesmas di sekitar BRSU Tabanan dan dirujuk dengan membawa surat rujukan dan hasil pemeriksaan laboratorium dari puskesmas. Selanjutnya dilakukan pendataan terhadap gejala klinis dan infeksi oportunistik saat dilakukan konseling di klinik VCT BRSU Tabanan.

\section{HASIL}

Hasil dari penelitian ini yang dilakukan dari Januari 2009 hingga Agustus 2017 didapatkan 872 sampel pasien baru yang terdiagnosis HIV pada poliklinik VCT BRSU Tabanan. Dari 872 sampel didapatkan bahwa jumlah pasien terbanyak adalah pada tahun 2016 dan paling sedikit pada tahun 2009 terlihat pada tabel 1.

Pada Tabel 2 sampai 6 terlihat karakteristik dasar dari sampel yang meliputi Umur, Jenis kelamin, Pekerjaan dan Status Pasien terakhir

\begin{tabular}{lcc} 
Tabel 1 & \multicolumn{3}{l}{$\begin{array}{l}\text { Jumlah Sampel Berdasarkan } \\
\text { Tahun }\end{array}$} \\
\hline Tahun & Jumlah & Persen (\%) \\
\hline 2009 & 54 & 6,2 \\
2010 & 82 & 9,4 \\
2011 & 101 & 11,6 \\
2012 & 64 & 7,3 \\
2013 & 113 & 13,0 \\
2014 & 110 & 12,6 \\
2015 & 105 & 12,0 \\
2016 & 161 & 18,5 \\
2017 & 82 & 9,4 \\
Jumlah & 872 & 100 \\
\hline
\end{tabular}

\section{Tabel 2 Distribusi Sampel Menurut} kelompok umur

\begin{tabular}{lcc}
\hline Kelompok Umur & Jumlah & Persen (\%) \\
\hline 0 - 5 Tahun & 41 & 4,7 \\
6 - 17 Tahun & 5 & 6 \\
18 - 29 Tahun & 255 & 29,2 \\
30 - 39 Tahun & 304 & 34,9 \\
40 - 49 Tahun & 160 & 18,3 \\
- 59 Tahun & 77 & 8,8 \\
>5 Tahun & 30 & 3,4 \\
Jumlah & 872 & 100 \\
\hline
\end{tabular}


Tabel 3 Distribusi sampel Menurut Pekerjaan

\begin{tabular}{lcc}
\hline Pekerjaan & Jumlah & Persen (\%) \\
\hline Wiraswasta & 144 & 16,5 \\
Karyawan & 195 & 22,4 \\
Ibu RT & 149 & 17,2 \\
Petani & 111 & 12,7 \\
Buruh & 82 & 9,4 \\
Seniman & 11 & 1,3 \\
Pekerja Tunasusila & 21 & 2,4 \\
Supir & 32 & 3,7 \\
Lain - Lain & 81 & 9,3 \\
Tidak Bekerja & 46 & 5,3 \\
Jumlah & 872 & 100 \\
\hline
\end{tabular}

Tabel 4 Distribusi Sampel Menurut Status Pasien

\begin{tabular}{lcc}
\hline Status Pasien & Jumlah & Persen (\%) \\
\hline Hidup & 819 & 93,9 \\
Meninggal akibat WS & 22 & 2,5 \\
Meninggal akibat PCP & 23 & 2,6 \\
Meninggal akibat Bunuh Diri & 1 & 0,1 \\
Meninggal akibat Toxoplasmosis & 4 & 0,5 \\
Meninggal akibat penyebab lainnya & 3 & 0,3 \\
Jumlah & 872 & 100 \\
\hline
\end{tabular}

Tabel 5 Distribusi Sampel Menurut Stadium Penyakit

\begin{tabular}{lcc}
\hline Stadium Penyakit & Jumlah & Persen (\%) \\
\hline Stadium 1 & 244 & 28,0 \\
Stadium 2 & 38 & 4,4 \\
Stadium 3 & 467 & 53,6 \\
Stadium 4 & 123 & 14,1 \\
Jumlah & 872 & 100 \\
\hline
\end{tabular}

Tabel 6 Distribusi Sampel Menurut Perkiraan Faktor Risiko

\begin{tabular}{lcc}
\hline Perkiraan Faktor Risiko & Jumlah & Persen (\%) \\
\hline Heteroseksual & 817 & 93,7 \\
Homoseksual & 11 & 1,3 \\
Perinatal & 38 & 4,6 \\
Biseksual & 3 & 0,3 \\
Narkoba Suntik & 3 & 0,3 \\
Jumlah & 872 & 100 \\
\hline
\end{tabular}

Tabel 7 Gambaran Gejala Klinis Pada Sampel

\begin{tabular}{lcc}
\hline Gejala Klinis & Jumlah & Persen (\%) \\
\hline $\begin{array}{l}\text { Berat badan menurun } \\
>10 \% \text { dalam 1 bulan }\end{array}$ & 499 & $50,2 \%$ \\
$\begin{array}{l}\text { Demam brkepanjangan } \\
\text { lebih dr 1 bulan }\end{array}$ & 190 & $19,1 \%$ \\
$\begin{array}{l}\text { Dimensia/ HIV } \\
\text { encefalopati }\end{array}$ & 3 & $0,3 \%$ \\
$\begin{array}{l}\text { Diare kronis yg } \\
\text { brlangsung lbh dr 1 bulan }\end{array}$ & 122 & $12,3 \%$ \\
$\begin{array}{l}\text { Penurunan kesadaran \& } \\
\text { gangguan neurologis }\end{array}$ & 11 & $1,1 \%$ \\
$\begin{array}{l}\text { Batuk menetap lebih dari } \\
\text { bulan }\end{array}$ & 135 & $13,6 \%$ \\
$\begin{array}{l}\text { Gejala Pada Kulit dan } \\
\text { Kelamin }\end{array}$ & 34 & $3,4 \%$ \\
$\begin{array}{l}\text { Limfadenopati } \\
\text { generalisata }\end{array}$ & 1 & $0,1 \%$ \\
\hline
\end{tabular}

\section{Tabel 8 Gambaran Infeksi Oportunistik} Pada Sampel

\begin{tabular}{lcc}
\hline Gejala & Jumlah & Persen \\
\hline TBC & 61 & $8,6 \%$ \\
Kandidiasis & 395 & $55,6 \%$ \\
Sarkoma Kaposi & 2 & $0,3 \%$ \\
Limfadenopati Generalisata & 5 & $0,7 \%$ \\
Persisten & & \\
Toxoplasmosis & 26 & $3,7 \%$ \\
Koksidiomikosis & 1 & $0,1 \%$ \\
Diare Kronis & 82 & $11,5 \%$ \\
Dermatitits & 55 & $7,7 \%$ \\
Encephalopaty & 4 & $0,6 \%$ \\
Wasting Syndrome & 23 & $3,2 \%$ \\
Pneumonia yang mengancam & 56 & $7,9 \%$ \\
Jiwa dan Berulang & & \\
\hline
\end{tabular}

sebelum dilakukan penelitian. Dimana dari hasil tersebut diketahui bahwa usia sampel terbanyak adalah 30 - 39 tahun, jenis kelamin yang terbanyak adalah laki - laki, perkerjaan terbanyak adalah karyawan, status sampel terbanyak saat ini adalah hidup, stadium penyakit sampel terbanyak adalah stadium 3, dan perkiraan faktor risiko terbanyak adalah heteroseksual. 
Gejala Klinis pada sampel yang terbanyak adalah Berat Badan Menurun $>10 \%$ dalam 1 bulan dan disusul dengan Demam berkepanjangan lebih dari 1 bulan sesuai pada Tabel 7. Pada satu orang sampel bisa terdapat lebih dari satu gejala klinis.

Infeksi Oportunistik terbanyak dari sampel adalah Kandidiasis dan berikutnya adalah Diare Kronis seperti yang tertera pada tabel 8. Pada satu orang sampel bisa terdapat lebih dari satu Infeksi Oportunistik.

\section{PEMBAHASAN}

Jumlah pasien yang terdiagnosis HIV pada poliklinik VCT BRSU Tabanan dari tahun 2009 hingga tahun 2017 mengalami peningkatan dan penurunan tiap tahunnya, tetapi secara umum terdapat peningkatan kasus setiap tahun dimana puncaknya pada tahun 2016 terdapat 161 kasus baru. Hal ini berbeda jika dibandingkan angka kejadian baru HIV di dunia, berdasarkan data UNILADS terjadi penurunan angka kejadian baru HIV dari 2,1 juta pada tahun 2010 menjadi 2,2 juta pada tahun $2015 .{ }^{1}$ Hal ini berbeda dari data WHO mengenai HIV di Asia Tenggara, walaupun terjadi tren penurunan kasus baru HIV di beberapa Negara Asia Tenggara namun tidak untuk Indonesia. Berdasarkan penelitian tersebut dinyatakan bahwa Indonesia adalah Negara yang sedang mengalami peningkatan kasus baru HIV. ${ }^{6}$ Banyak hal yang memicu peningkatan jumlah kasus tersebut baik karena semakin banyaknya program deteksi dini pada kelompok berisiko dan semakin tingginya kesadaran masyarakat untuk melakukan pemeriksaan sendiri.

Berdasarkan penelitian kelompok umur sampel yang tertinggi adalah pada kelompok umur 30 - 39 tahun dan 18 - 29 tahun yaitu 34,9\% dan $29,2 \%$. Data tersebut menunjukkan hasil yang sama dengan Kementerian Kesehatan Republik Indonesia mengenai kasus baru HIV di Indonesia. Berdasarkan data kementerian kesehatan kelompok umur terbanyak adalah 20 - 29 tahun dan 30 - 39 tahun. $^{7}$ Hal ini juga menunjukkan hal sama dari data Kabupaten Tabanan mengenai pasien HIV baru pada tahun 2015, pada data tersebut didapatkan $67,6 \%$ adalah pada kelompok umur 25 - 49 tahun. ${ }^{3}$ Kelompok umur tersebut merupakan kelompok yang paling produktif dan aktif dalam hubungan seksual. Sehingga bila tidak dilakukan edukasi yang baik, pencegahan, serta deteksi dini akan meningkatkan terjadinya risiko penularan HIV. Baik penularan melalui pasangan seksual maupun dari ibu ke janinnya.

Jenis kelamin terbanyak sampel adalah laki laki dibandingkan perempuan, yaitu $60,1 \%$ dari seluruh sampel. Sesuai dengan data epidemiologi
UNILADS pada penderita HIV baru tahun 2015 di dunia, dimana persentase pada laki-laki adalah 53\%. ${ }^{1}$ Dan secara nasional dari tahun 2008 - 2014 jenis kelamin laki-laki lebih tinggi dari pada perempuan. ${ }^{7}$ Berdasarkan hasil penelitian di India laki-laki lebih mudah terinfeksi HIV karena lebih cenderung melakukan tindakan berisiko dibandingkan perempuan seperti melakukan hubungan seks dengan multi partner, berhubungan seks dengan sesama jenis dan injeksi narkotika. Sehingga laki-laki selain lebih berisiko terinfeksi HIV juga berperan besar dalam penyebarannya. ${ }^{8}$

Pekerjaan dari sampel yang terbanyak adalah sebagai karyawan yaitu 22,4\%, Ibu Rumah Tangga $17,2 \%$ dan wiraswasta 16,5\%. Hasil ini mirip dengan data Menteri Kesehatan Indonesia tahun 2014, dimana menurut data Menkes pekerjaan tertinggi adalah Ibu Rumah Tangga 21,4\%, wiraswasta, 20,3\% dan karyawan 18,4\%.7 Walaupun secara nasional hasil menunjukkan hal yang sama tetapi jika dibandingkan dengan daerah lainnya bisa saja menunjukkan hasil yang berbeda. Perbedaan tersebut bisa disebabkan karena faktor sosiokultural dan lingkungan dari setiap daerah. Berdasarkan data dari pusat statistik Nasional provinsi Bali tahun 2013 pekerjaan terbanyak adalah sebagai Karyawan, yaitu sebanyak 1.009,28 ribu orang atau $44,39 \%$ dan pekerjaan terbanyak berikutnya adalah wiraswasta. ${ }^{9}$ Karena jumlah populasi pekerjaan yang besar tersebut maka Karyawan menjadi pekerjaan terbanyak pasien yang terdiagnosis baru HIV pada poliklinik VCT BRSU Tabanan

Ibu Rumah Tangga adalah salah satu pekerjana yang cukup tinggi terinfeksi HIV. Bahkan jika dibandingkan dengan Pekerja Tunasusila (Wanita penjaja seks) perbandingan presentasinya cukup jauh. Yaitu Ibu Rumah Tangga 17,2\% dan Pekerja Tunasusila 2,4\%. Hal ini serupa dengan data Kementerian Kesehatan Indonesia tahun 2014, didapatkan data bahwa secara Nasional Wanita Pekerja Seksual jauh lebih rendah dibandingkan dengan Ibu Rumah Tangga yaitu 6,7\% Wanita Pekerja Seksual dan 21,4\% pada Ibu Rumah Tangga. ${ }^{7}$ Secara risiko sebenarnya Ibu rumah tangga tidak termasuk populasi kunci, sedangkan Pekerja Seks merupakan populasi kunci. ${ }^{10}$ Tetapi tingginya angka kejadian pada ibu rumah tangga dibandingkan pada Pekerja Seksual diakibatkan banyak faktor. Umumnya Ibu rumah tangga tertular HIV dari pasangannya sendiri. ${ }^{8}$ Berdasarkan data penelitian dari Malaysia di dapatkan Ibu Rumah tangga tertular HIV tanpa mereka ketahui dan dari penelitian tersebut sebagian besar pasangan mereka tertular HIV melalui penggunaan obat-obatan terlarang dan berganti-ganti pasangan seksual. Sebagian besar Pekerja Seksual menyadari pekerjaannya berisiko terkena infeksi 
HIV dan mengerti bagaimana cara penularannya, sehingga sebagian besar pekerja seks lebih waspada saat melayani pelanggannya seperti menggunakan kondom. Selain karena kesadaran risiko pekerja seks mereka umumnya berasal dari kalangan yang kurang mampu sehingga tidak terlalu sering melakukan pengecekan kesehatan bila dibandingkan dengan ibu rumah tangga. Sebagian besar pekerja seks di Negara berkembang bersifat ilegal sehingga banyak kasus yang tidak dilaporkan dan menyebabkan jauhnya perbedaan angka pekerja seks dan ibu rumah tangga. ${ }^{11}$

Status dari sampel sampai dengan saat ini sebagian besar masih hidup yaitu 93,9\% dan sisanya meninggal yang sebagian besar akibat komplikasi dari infeksi oportunistik pasien yaitu wasting syndrome $(2,5 \%)$, pneumocystic pneumonia $(2,6 \%)$, dan toxoplasmosis ( $0,5 \%)$. Tingginya angka sampel yang masih hidup sesuai dengan angka penelitian UNILADS secara global. Pada data tersebut didapatkan pada tahun 2010 orang yang hidup dengan HIV 33,3 juta jiwa meningkat menjadi 36,7 juta jiwa pada tahun $2015 .{ }^{1}$ Meningkatnya angka harapan hidup dari pasien HIV adalah karena penggunaan Antiretroviral (ARV) yang semakin baik. Dengan penggunaan ARV membantu penderita untuk mendapatkan kualitas hidup yang lebih baik dan harapan hidup yang lebih panjang. ${ }^{12}$

Penyebab kematian terbanyak dari sampel adalah komplikasi dari infeksi oportunistik pasien. Hal ini sesuai dengan penelitian yang dilakukan Sara Croxford di Inggris dari tahun 1997 hingga 2012 didapatkan dari seluruh sampel yang meninggal 58\% sampel meninggal akibat infeksi oportunistik..$^{13}$ Sehingga perlu adanya pencegahan dan penanganan yang lebih lanjut untuk menekan penyebab kematian akibat infeksi oportunistik.

Sampel dilakukan grading stadium klinis berdasarkan klasifikasi WHO saat pertama kali terdiagnosis. Dari hasil grading didapatkan sebagian besar sampel berada pada stadium lanjut yaitu stadium $3(53,6 \%)$ dan stadium 4 (14,1\%). Hasil ini menunjukkan hasil yang serupa dengan penelitian yang dilakukan John dkk di Bangalore tahun 2014. Pada penelitian tersebut di dapatkan pasien yang datang ke pusat kesehatan sudah dalam stadium lanjut yaitu $86,1 \%$ pada stadium IV. ${ }^{14}$ Masih tingginya sampel yang datang dengan stadium lanjut pada klinik VCT, merupakan hal yang perlu diperhatikan. Klinik VCT akan lebih baik jika mendeteksi pada stadium yang lebih awal, karena pada stadium awal penanganan dan pencegahan penularan akan lebih mudah dilakukan. Hal ini menunjukkan masih rendahnya tingkat pengetahuan masyarakat mengenai penularan HIV dan gejala awal dari HIV yang menyebabkan banyaknya sampel yang datang dalam fase lanjut.
Perkiraan faktor risiko tertinggi dari sampel adalah heteroseksual $(93,7 \%)$, perinatal $(4,6 \%)$, dan homoseksual (1,3\%). Hal ini serupa dengan data penelitian John dkk dimana faktor risiko utama adalah heteroseksual (93,5\%), narkoba suntik $(2,2 \%)$, dan homoseksual $(1,3 \%){ }^{14}$ Data tersebut juga menyerupai data Menteri Kesehatan Nasional tahun 2015 didapatkan data heteroseksual $(61,5 \%)$, Narkoba suntik (15,2\%), Perinatal (2,7\%), dan homoseksual $(2,4 \%){ }^{7}$ Heteroseksual merupakan faktor risiko utama penularan HIV. Umumnya hubungan seks dilakukan dengan lebih dari satu partner dan tidak menggunakan pengaman. Selain heteroseksual faktor risiko lainnya yang penting adalah homoseksual dan penggunaan narkoba suntik. Berdasarkan penelitian di New Delhi India didapatkan bahkan kelompok homoseksual risikonya lebih tinggi terkena HIV. Salah satu faktor penyebabnya adalah rendahnya penggunaan pengaman pada kelompok homoseksual. ${ }^{8}$ Penting adanya edukasi mengenai penularan HIV melalui hubungan seksual pada kelompok yang berisiko, karena masih tingginya angka penularan HIV melalui hubungan seks.

Transmisi dari ibu ke anak (Perinatal) merupakan perkiraan faktor risiko terbesar kedua dalam penelitian ini $(4,6 \%)$. Data dari menteri kesehatan juga menunjukkan hal yang hampir sama, transmisi dari ibu ke anak merupakan faktor risiko terbesar ke tiga (2,7\%). ${ }^{7}$ Fasilitas-fasilitas kesehatan di Indonesia sudah sejak dahulu menjalankan program pemeriksaan pada ibu hamil dan pemberian terapi pada ibu hamil yang terinfeksi HIV. Tetapi kesadaran masyarakat untuk melakukan pemeriksaan pada masa kehamilan masih rendah. Transmisi dari ibu yang terinfeksi HIV ke anak sebenarnya dapat dicegah dengan penggunaan ARV. Berbagai jenis ARV kini telah ditemukan dan dapat membantu menurunkan angka virulensi HIV. Penggunaan ARV cukup efektif dalam menurunkan angka penularan dari ibu ke anaknya dalam masa kehamilan. ${ }^{15}$ Untuk itu perlu adanya edukasi pada ibu hamil yang terinfeksi HIV bahwa penularan HIV dapat dicegah dengan menggunakan ARV.

Sampel saat pertama kali didiagnosis HIV dilakukan pemeriksaan gejala klinis. Berdasarkan gejala klinis sampel, gejala klinis terbanyak adalah Berat badan menurun $>10 \%$ dalam satu bulan (50,2\%), Demam berkepanjangan lebih dari satu bulan $(19,1 \%)$, dan batuk menetap lebih dari satu bulan (13,6\%). Hasil ini menyerupai hasil penelitian Antwal dkk di India tahun 2014, gejala klinis tertinggi adalah demam (28,4\%), Riwayat Herpes Zoster (25,9\%), Kehilangan nafsu makan $(21,1 \%)$, dan Batuk dengan dahak (17,1\%). Gejala klinis dari HIV sangat berkaitan dengan infeksi 
oportunistiknya. Pada penelitian ini dan penelitian Antwal dkk, gejala awal sampel menyerupai gejala TB (Demam berkepanjangan, penurunan berat badan, dan batuk lama). Sehingga perlu adanya pemeriksaan HIV pada pasien dengan gejala TB. ${ }^{16}$

Selain gejala klinis, saat pertama kali didiagnosis sampel juga dilakukan pendataan infeksi oportunistik yang ada. Berdasarkan hasil penelitian infeksi oportunistik terbanyak pada sampel adalah Kandidiasis (55,6\%), Diare kronis $(11,5 \%)$, dan TBC $(8,6 \%)$. Dalam penelitian ini Kandidiasis merupakan infeksi oportunistik terbanyak pada sampel, hal ini sesuai dengan literatur yang ada, dimana kandidiasis merupakan infeksi oportunistik tersering pada pasien dengan HIV. Penyebab utama infeksi kandidiasis adalah jamur Candida Spp. dan Candida Albican. Dalam keadaan normal jamur tersebut dapat hidup di dalam mukosa tubuh manusia dan hanya akan menyebabkan infeksi bila terjadi kondisi tertentu seperti penurunan imunitas tubuh. Adanya infeksi Kandidiasis orofaringeal dan Kandidiasis oroesofageal merupakan tanda terjadinya imunodefisiensi pada seseorang. ${ }^{17}$

\section{KESIMPULAN}

HIV adalah penyakit yang kini sudah menjadi masalah global. Bali merupakan salah satu provinsi dengan kasus baru HIV yang sangat tinggi. Badan Rumah Sakit Umum (BRSU) Tabanan adalah salah satu rumah sakit utama di kabupaten Tabanan. Berdasarkan data poliklinik VCT BRSU Tabanan pasien baru terdiagnosis HIV tahun ke tahun terus mengalami peningkatan, sehingga perlu dilakukan penelitian profil pasien baru HIV.

Dari hasil penelitian didapatkan kasus baru terbanyak pada tahun 2016. Dengan karakteristik terbanyak pada usia produktif dan aktif secara seksual, laki-laki, pekerjaan karyawan, status hidup dan perkiraan faktor risiko heteroseksual. Pada saat terdiagnosis HIV sebagian besar pada stadium lanjut, dengan gejala klinis terbanyak berat badan menurun $>10 \%$ dalam satu bulan, dan infeksi oportunistik terbanyak adalah Kandidiasis. Dalam upaya menurunkan angka penularan HIV pemberian edukasi mengenai infeksi menular seksual dan kesehatan reproduksi merupakan hal yang penting, terutama pada kelompok yang berisiko tinggi.

\section{DAFTAR PUSTAKA}

1. UNAIDS. Global AIDS Update 2016. Joint United Nations Programme on HIV/AIDS. 2016. pp: 1 - 13

2. Kementrian Kesehatan Republik Indonesia. Data dan Informasi Profil Kesehatan Indonesia 2016. Pusat Data dan Informasi Kementrian Keshatan RI. 2017, pp: 119 - 121

3. Dinas Kesehatan Kabupaten Tabanan. PROFIL KESEHATAN KABUPATEN TABANAN Tahun 2016. pp:28 - 31

4. Profil BRSU Tabanan. 2017. Diakses pada: https://brsu. tabanankab.go.id/profile/

5. Data Poliklinik VCT BRSU Tabanan Kabupaten Tabanan Bali 2017

6. World Health Organization. HIV/AIDS in the SouthEast Asia Region: Progress Report 2011. WHO Library Cataloguing 2012, pp:1 - 136

7. Kemetrian Kesehatan RI. Situasi dan Analisis HIV AIDS. Infodatin Pusat Data dan Informasi 2014, pp: 1 - 6

8. Silan V, Kant S, Haldar P, Goswami K, Rai SK, Misra P. HIV Risk Behaviour Among Men Who Have Sex with Men. North America Journal of Medical Science. 2013. September; 5(9) pp: 515 - 522

9. Badan Pusat Statistik Provinsi Bali. Laporan Bulanan Data Sosial Ekonomi Provinsi Bali 2014. Katalog BPS: 9199017.51. 2014. pp: 1 - 83

10. Kementrian Kesehatan RI. Estimasi Jumlah Populasi Kunci Terdampak HIV Tahun 2012. Kementerian Kesehatan Republik Indonesia 2014. pp: 1 - 22

11. Najimudeen M., Mat Rosy M. More HIV Infection Among Housewvies Than Sex Workers In Malaysia. Webmedcentral. 2012. pp:1-8

12. Nakagawa F, May M, Philips A. Life Expectancy Living With HIV: recent estimate and future implication. Wolters Kluwer Health. 2013. Vol 26(1); pp: 17 - 25

13. Croxford S, Kitching A, Desai S, Kall M, Edelstein M, Skingsley A, Burns F, Copas A, Brown AE, Sullivan AK, Delpech V. Mortality and causes of death in people diagnosed with HIV in the era of highly active antiretroviral therapy compared with the general population: an analysis of a national observational cohort. Lancet Public Health. 2017. Vol 2; pp:e35-e46

14. John S, Kishore G, Meera NK. Profile of HIV Patients with Opportunistic Infections in a Tertiary Care Hospital in Bangalore. International Journal of Advances in Pharmacy, Biology and Chemistry. 2014. Vol 3(1);pp: 110 - 115

15. Departement of Health and Human Service. Recommendations for Use of Antiretroviral Drugs in Pregnant HIV-1-Infected Women for Maternal Health and Interventions to Reduce Perinatal HIV Transmission in the United States. 2011. pp:1 - 207

16. Antwal M, Gurjar R, Chidrawar S, Pawar J, Gaikwad S, Panchal N, Kale V, Thakar M, Risbud A, Tripathy S. Clinical profile of HIV infected patients attending a HIV referral clinic in Pune, India. Indian J Med Res 140. 2014. pp: 271-277

17. Bonafe SM, Caceres NA, Vieira MMC, Vieira IF, Monteleone VF, Neto LJM. Opportunistic Infection in AIDS Patient. iMedPub Journals. 2015 Vol. 7 No. 5:10; pp: 1 - 17

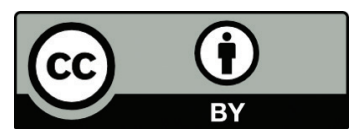

This work is licensed under a Creative Commons Attribution 